\title{
Executive Coaching: An Integrative Literature Review
}

\author{
James E. Bartlett II, Robert V. Boylan, Jimmie E. Hale \\ North Carolina State University, Raleigh, USA \\ Email: j.hale@wingate.edu
}

Received 13 September 2014; revised 15 October 2014; accepted 12 November 2014

Academic Editor: Denis Morin, Université du Québec à Montréal, Canada

Copyright (c) 2014 by authors and Scientific Research Publishing Inc.

This work is licensed under the Creative Commons Attribution International License (CC BY).

http://creativecommons.org/licenses/by/4.0/

\section{c) (i) Open Access}

\begin{abstract}
Executive coaching literature was investigated to uncover common themes within definitions, models and approaches, and effectiveness. An integrative literature review of 533 publications found relationship, goals, performance, and learning to be keywords used most often in defining executive coaching. The most prominent approaches included cognitive, and goal oriented coaching. Effectiveness was most often described as goal achievement, quality of relationships, and levels of trust and support. Finally, executive coaching was summarized as consisting of two critical tasks: 1) establishing a collaborative relationship, and 2) enhancing the vision of the learner. Effectiveness was determined by success in developing and implementing a systematic process that may be adapted to each learner and demonstrating the patience necessary to allow change to occur.
\end{abstract}

\section{Keywords}

Executive Coaching, Models, Definitions, Effectiveness

\section{Introduction}

Executive coaching (EC), both in the United States and abroad, is experiencing explosive growth. What began as developmental counseling in the 1960s evolved throughout the 1980s, 1990s, and 2000s into its present day form [1]. The International Coach Federation (ICF) reports an excess of 15,000 members [2]. Beyond its own ranks the federation estimates over 30,000 practitioners in the business of executive coaching, though exact numbers are difficult to attain. Scholars and practitioners alike point to unparalleled amounts of individual and 
organizational change as a key driver in the rapid rise of EC engagements [3]. To address these changes, individuals and organizations have sought out EC for individual performance improvement, leadership development, skill building, human resource acquisition and retention, and problem resolution [1].

EC remains largely a practice based discipline [4] [5]. The substantial increase in scholarly literature matches the growth of the discipline in practice. Evidence of coaching literature tracks back to the late 1930s but the vast majority of writing has occurred over the past ten years [6]. While the volume of writing has increased significantly, evidenced based research and empirical study of EC have not [7] [8]. The growth of EC has also created considerable discussion around what the practice really is, and more specifically, how it relates to its cousins mentoring, counseling, and consulting [8]-[10]. It is not the purpose of this paper, however, to provide an analysis of the similarities and differences of these seemingly similar disciplines. Rather, the purpose is to investigate the extant literature on EC to uncover common themes around models and approaches used, definitions, and effectiveness in EC.

\section{Research Design}

This study follows principles of an integrative literature review set forth by Torraco [11]. The integrative literature review methodology establishes a research protocol informing data collection, scrutiny of data collected, presentation of the data, and finally, the amalgamation of certain findings from the thorough review of literature on a topic [11]. This approach seems particularly appropriate given the current state of EC research and the specific research questions this study intends to answer.

\section{Research Questions}

Three specific research questions drove the design, implementation, and presentation of this study:

1) How does the literature define EC?

2) What coaching models or approaches are commonly used in EC?

3) How is effectiveness of the executive coach determined and measured?

\section{Data Collection and Analysis}

Three primary sources were used for data collection: Google Scholar, EBSCO Host, and finally, an annotated bibliography prepared by Grant [12]. Keywords used included executive coaching, definitions, models, and effectiveness. Additional search parameters excluded the use of the words nursing, athlete, and teachers, and focused specifically on the time frame 2007-2010. The aforementioned search criteria best served the study's intention of investigating recent research related to the research questions.

The initial search query based on the research criteria listed above returned 533 results. This number excludes the number of entries in Grant's annotated bibliography numbering 518 [12]. The list of 533 publications was further refined by reviewing both the abstract and conclusion of the scholarly publication in question. The following criteria informed further refinement of the search:

- Only peer reviewed journal articles were considered, eliminating books and other publications.

- Articles referencing internal coaching were discarded.

- Only publications focusing on external EC were retained.

- Publications with specific references to definitions, models or approaches, and effectiveness were retained. Publications not specifically mentioning these terms were discarded.

- Three exceptions to these criteria:

- Kampa-Kokesch \& Anderson (2001) [10] was included due to the pervasiveness of its citing in the literature. Over $70 \%$ of the publications reviewed cited the article.

- Tompson et al. (2008) [1] was included due to its comprehensive review of the state of EC, credentials of the authors, and the extensive and impressive reference list used in their study.

- ICF (2010) [2] was included due to the IFC's growing recognition as the preeminent source for information on EC.

A list of 182 publications was retained from the original list of 533. Each of these articles was read in full, resulting in the retention of 54 publications for inclusion in the study. Finally, Torraco suggests four ways to classify newly synthesized learning: a research agenda, a new taxonomy, new models and frameworks, and 
cross disciplinary, cross theoretical analysis of new learning [11]. This study includes both the first and second approaches to data synthesis.

\section{Findings}

Data analysis of extant literature produced findings for each research question. Findings for each research question follow, with a summary of key words observed in the publications followed parenthetically by the number of studies in which the keyword was mentioned. A synthesized conclusion to research question 1, examining how EC is defined in the literature, found executive coaching to be a collaborative relationship (13) that supports (5) individuals by establishing clearly defined goals (13) and using a systematic process (5) that is solution focused (4). Important components to the process are action plans (4), intervention strategies (6), communication (8) (discussion, questioning, listening), and feedback (8). The desired result of an executive coaching engagement is for the learner to arrive at a point where self-reflection (9) allows for self-evaluation and self-correction, rendering the coach disposable. Further, executive coaching benefits individual's performance (16) and effectiveness (6). Executive coaching may result in behavior changes (4), enhance development (5), provide the learner with skills/tools (5) primarily used for improving interpersonal relations (4), and facilitate continued learning (10). Table 1 provides a summary of prominent keywords and their related articles.

Research question 2 centered on models or approaches used in EC. Table 2 outlines common keywords for models and approaches to EC. The aggregate growth of EC engagements has seen similar growth in the number and nature of models and approaches to these engagements [3]. Of the 27 publications referenced in the study, the most prominent approaches included cognitive (10), goal setting (7), strengths (6), solutions (4), developmental (4), diagnostic (3), self-awareness (2), and remedial or restorative (2). Well over half of the publications reviewed referenced the essential need to assess coachee readiness for change, emphasizing the important point that underpinning all approaches is the basic tenant of human change. Cognitive approaches assist the coachee in better understanding how patterns of thought motivate action [30]. Goal setting models focus coachee actions on targets for achievement in the future [6]. Strengths coaching isolate certain areas of strength possessed by the coachee with the intent of building on these strengths [31]. Solutions based coaching is problem centric and orients the coachee towards determining a solution to a specific problem [4]. Developmental coaching presumes the coachee has potential for advancement in a given work role but lacks certain skills to elevate to the next level. The coaching engagement addresses the skill gap [26]. Diagnostic coaching employs assessment protocols to evaluate both strengths and weaknesses of the coachee with the intent to establish plans of action to address findings uncovered from the assessment [32]. Self-awareness coaching engages the coachee in a process of self-discovery to better understand actions and behaviors [29]. Finally, remedial or restorative coaching takes corrective action on coachee weaknesses of deficiencies [33].

Finally, research question 3 focused on defining effectiveness of the coach. Table 3 outlines significant themes related to coaching effectiveness. It is important to distinguish effectiveness of the coaching engagement and the effectiveness of the coach. This study focuses on the latter.

Fifty-six articles weighed in on the subject of factors contributing to coaching effectiveness. A synthesized perspective of specific factors included providing clear mutual goals (30) tops the list as the most mentioned factor. Second, a collaborative relationship (21), often founded on trust (15) and resulting primarily from the coach's experience, and support (15) given by the coach were prominent. While empathy and encouragement are considered forms of support, research showed emotional control (5) by the coach to also be a factor. Further, a systematic process (15) that can be individually tailored (7) to providing solutions (7) results in an action plan (10). An action plan may include assessments (10), intervention strategies (8), and discussion (13) paired with focused listening (14) to establish accountability (12) for the learner and then provide feedback (13). Research showed the most sought after outcomes of the coaching engagement to be continued learning (7) and a heightened self-awareness (13) within the learner that results in self-regulation.

\section{Implications for Human Resource Development}

Swanson \& Holton suggest human resource development (HRD) can defined as “ $\ldots$ a process of developing and unleashing expertise for the purpose of improving individual, team, work process, and organizational system performance" ([59], p. 4). EC's focus on improving individual performance falls squarely within the purview of HRD. Accordingly, scholars and practitioners have an un-mandated responsibility to nurture understanding of 
Table 1. A range of keywords included in various definitions in retained publications for the study.

\begin{tabular}{|c|c|}
\hline Keyword(s) & Authors cited \\
\hline Performance & $\begin{array}{l}\text { Biswas-Diener (2009) [13], Chmielecki (2009) [14], Ellinger et al. (2008) [8], Fischer \& Beimers (2009) } \\
\text { [4], Grant (2007) [15], Grant et al. (2010) [6], Hui \& Sue-Chan (2009) [16], Ives (2008) [9], } \\
\text { Kutzhanova et al. (2009) [17], Neenan (2008) [18], Olson (2008) [19], Preiss \& Molina-Ray (2007) [20], } \\
\text { Sperry (2008) [21], Stewart et al. (2008) [22], Sthyre \& Josephson (2007) [23], Tompson et al. (2008) [1] }\end{array}$ \\
\hline $\begin{array}{l}\text { Collaborative } \\
\text { relationship }\end{array}$ & $\begin{array}{l}\text { Baron (2009) [7], Biswas-Diener (2009) [13], Chmielecki (2009) [14], Grant (2007) [15], Grant et al. } \\
\text { (2010) [6], Ives (2008) [9], Kutzhanova et al. (2009) [17], Olson (2008) [19], Preiss \& Molina-Ray (2007) } \\
\text { [20], Stewart et al. (2008) [22], Styhre \& Josesphson (2008) [24], Tompson et al. (2008) [1], } \\
\text { Ulrich (2008) [25] }\end{array}$ \\
\hline $\begin{array}{l}\text { Clear mutual } \\
\text { goals }\end{array}$ & $\begin{array}{l}\text { Biswas-Diener (2009) [13], Bowles et al. (2007) [26], Chmielecki (2009) [14], Fischer \& Beimers (2009) [4], } \\
\text { Grant et al. (2010) [6], Hui \& Sue-Chan (2009) [16], Ives (2008) [9], Kutzhanova et al. (2009) [17], Matthews } \\
\text { (2010) [27], Olson (2008) [19], Stewart et al. (2008) [22], Styhre \& Josephson (2007) [23], Ulrich (2008) [25] }\end{array}$ \\
\hline Learning & $\begin{array}{l}\text { Biswas-Diener (2009) [13], Bowles et al. (2007) [26], Ellinger et al. (2008) [8], Fischer \& Beimers (2009) [4], } \\
\text { Grant (2007) [15], Grant et al. (2010) [6], Neenan (2008) [18], Preiss \& Molina-Ray (2007) [20], } \\
\text { Stelter (2007) [28], Stewart et al. (2008) [22] }\end{array}$ \\
\hline Self-awareness & $\begin{array}{l}\text { Chmielecki (2009) [14], Du Toit (2007) [3], Grant (2007) [15], Greif (2007) [29], Ives (2008) [9], } \\
\text { Kombarakaran et al. (2008) [5], Olson (2008) [19], Stelter (2007) [28], Ulrich (2008) [25] }\end{array}$ \\
\hline Feedback & $\begin{array}{l}\text { Baron (2009) [7], Bowles et al. (2007) [26], Fischer \& Beimers (2009) [4], Grant et al. (2010) [6], } \\
\text { Kombarakaran et al. (2008) [5], Sperry (2008) [21], Styhre \& Josephson (2007) [23], Ulrich (2008) [25] }\end{array}$ \\
\hline Communication & $\begin{array}{l}\text { Du Toit (2007) [3], Ellinger et al. (2008) [8], Grant (2007) [15], Matthews (2010) [27], } \\
\text { Preiss \& Molina-Ray (2007) [20], Sperry (2008) [21], Stelter (2007) [28], Stewart et al. (2008) [22] }\end{array}$ \\
\hline Intervention & $\begin{array}{l}\text { Baron (2009) [7], Chmielecki (2009) [14], Fischer \& Beimers (2009) [4], Ives (2008) [9], } \\
\text { Sperry (2008) [21], Styhre \& Josephson (2007) [23] }\end{array}$ \\
\hline Effectiveness & $\begin{array}{l}\text { Baron (2009) [7], Ellinger et al. (2008) [8], Fischer \& Beimers (2009) [4], } \\
\text { Kombarakaran et al. (2008) [5], Styhre \& Josephson (2007) [23] }\end{array}$ \\
\hline Development & $\begin{array}{l}\text { Baron (2009) [7], Biswas-Diener (2009) [13], Chmielecki (2009) [14], } \\
\text { Hui \& Sue-Chan (2009) [16], Neenan (2008) [18] }\end{array}$ \\
\hline Skills & $\begin{array}{l}\text { Baron (2009) [7], Bowles et al. (2007) [26], Kombarakaran et al. (2008) [5], } \\
\text { Sperry (2008) [21], Styhre \& Josephson (2007) [23] }\end{array}$ \\
\hline Systematic process & Bowles et al. (2007) [26], Greif (2007) [29], Ives (2008) [9], Olson (2008) [19], Stewart et al. (2008) [22] \\
\hline Support & $\begin{array}{l}\text { Ellinger et al. (2008) [8], Ives (2008) [9], Komarakaran (2008) [5], } \\
\text { Matthews (2010) [27], Preiss \& Molina-Ray (2007) [20] }\end{array}$ \\
\hline Interpersonal relations & Bowles et al. (2007) [26], Fischer \& Beimers (2009) [4], Sperry (2008) [21], Stelter (2007) [28] \\
\hline Behavioral change & Chmielecki (2009) [14], Grant et al. (2010) [6], Kombarakarn et al. (2008) [5], Kutzhanova et al. (2009) [17] \\
\hline Action plan & Grant (2007) [15], Grant et al. (2010) [6], Kutzhanova et al. (2009) [17], Neenan (2008) [18] \\
\hline Solution based & Ives (2008) [9], Kutzhanova et al. (2009) [17], Matthews (2010) [27], Olson (2008) [19] \\
\hline Growth & Du Toit (2007) [3], Greif (2007) [29], Stelter (2007) [28] \\
\hline Strengths based & Baron (2009) [7], Grant et al. (2010) [6], Olson (2008) [19] \\
\hline Individually tailored & Greif (2007) [29], Kutzhanova et al. (2009) [17], Preiss \& Molina-Ray (2007) [20] \\
\hline Guidance & Ellinger et al. (2008) [8], Preiss \& Molina-Ray (2007) [20] \\
\hline Trust & Kutzhanova et al. (2009) [17], Ulrich (2008) [25] \\
\hline Establish accountability & Grant et al. (2010) [6] \\
\hline Motivation & Ives (2008) [9] \\
\hline Strategy realization & Ives (2008) [9] \\
\hline Assessment & Preiss \& Molina-Ray (2007) [20] \\
\hline
\end{tabular}

EC both in scholarly inquiry and practical application. Tompson et al. report that $50 \%$ of companies studied self-identify as employing EC currently [1]. Full one third of those companies surveyed not currently engaging EC express interest in adding the practice in the future. Of particular importance will be HRD's informed interaction with the psychology community in continuing to define the purpose and uses of EC, EC's relationship to mentoring, counseling, and consulting, and perhaps most importantly, what entity emerges as the leader of EC's fate as an emerging profession. 
Table 2. A range of keywords involving models and approaches to EC in retained publications for the study.

\begin{tabular}{ll}
\hline Models and approaches & Keywords and phrases \\
\hline & Beddoes-Jones \& Miller (2007) [30], Neenan (2008) [18], Palmer (2007) [34], \\
Cognitive & Passmore (2007) [35], Passmore (2007) [36], Stewart et al. (2008) [22], Ives (2008) [9], \\
& Hui \& Sue-Chan (2009) [16], Kemp (2008) [37], Barner \& Higgins (2007) [38] \\
& Du Toit (2007) [3], Grant et al. (2010) [6], Grant (2007) [15], Grant (2007) [39], Ives \\
Goal setting & (2008) [9], Spence (2007) [40], Barner \& Higgins (2007) [38] \\
& Gordon (2008) [31], Govindji \& Linley (2007) [41], Kutzhanova et al. (2009) [17], \\
Strengths coaching & Linley et al. (2009) [42], Naficy \& Isabella (2008) [43], Ives (2008) [9] \\
& Fischer \& Beimers (2009) [4], Grant \& O’Connor (2010) [44], \\
Solutions based & Grant et al. (2010) [6], Stewart et al. (2008) [22] \\
Developmental, competency based & Bowles et al. (2007) [26], Hauser (2009) [33], Laske (2007) [45], Kutzhanova et al. (2009) [17] \\
Diagnostic, assessment & Grant et al. (2010) [6], McDowall \& Kurz (2007) [46], Nelson \& Hogan (2009) [32] \\
Self-awareness & Grief (2007) [29], Stewart et al. (2008) [22] \\
Remedial, restorative & Hauser (2009) [33], Kutzhanova et al. (2009) [17] \\
\hline
\end{tabular}

Table 3. A range of keywords and phrases defining effectiveness of the coach in EC in retained publications for the study.

Keywords and phrases $\quad$ Referenced articles

Ability to engage in an intervention through establishment of clear accountability and strong communication

Ability to manage goal setting process with coachee

Ability to establish strong, collaborative relationships

Exhibits strong planning skills

Ability to achieve results
Baron \& Morin (2009) [7], Baron \& Morin (2010) [47], Biswas-Deiner (2009) [13], Bowles et al. (2007) [26], Chmielecki (2009) [14], Ellinger et al. (2008) [8], Feggetter (2007) [48], Fischer \& Beimers (2009) [4], Gordon (2008) [31], Grant (2007) [15], Grant et al. (2010) [6], Gyllensten \& Palmer (2007) [49], Hauser (2009) [33], Hui \& Sue-Chan (2009) [16], Ives (2008) [9], Kauffman \& Bachkirova (2008) [50], Kemp (2009) [51], Kombarakarn et al. (2008) [5], Kutzhanova et al. (2009) [17], Laske (2007) [45], Linley et al. (2009) [42], Mackie (2007) [52], Matthews (2010) [27], McDowall \& Kurz (2007) [46], Naficy \& Isabella (2008) [43], Neenan (2008) [18], Nelson \& Hogan (2009) [32], Newton et al. (2008) [53], Olson (2008) [19], Passmore \& Marianetti (2007) [54], Passmore \& Gibbes (2007) [55], Spence (2007) [40], Sperry (2008) [21], Stelter (2007) [28], Sthyre \& Josephson (2007) [23], Ulrich (2008) [25]

Baron \& Morin (2009) [7], Biswas-Diener (2009) [13], Chmielecki (2009) [14], Ellinger et al. (2008) [8], Feggetter (2007) [48], Fischer \& Beimers (2009) [4], Grant (2007) [15], Grant (2007) [39], Grant et al. (2010) [6], Grief (2007) [29], Gyllensten \& Palmer (2007) [49], Hauser (2009) [33], Hui \& Sue-Chan (2009) [16], Ives (2008) [9], Kauffman \& Bachkirova (2008) [50], Kutzhanova et al. (2009) [17], Levleva \& Terry (2008) [56], Mackie (2007) [52], Matthews (2010) [27], Neenan (2008) [18], Nelson \& Hogan (2009) [32], Olson (2008) [19], Passmore \& Gibbes (2007) [55], Spence (2007) [40], Stewart et al. (2008) [22], Tompson et al. (2008) [1], Ulrich (2008) [25]

Baron \& Morin (2009) [7], Baron \& Morin (2010) [47], Biswas-Diener (2009) [13], Bowles et al.(2007) [26], Chmielecki (2009) [14], Cox \& Bachkirova (2007) [57], Day et al. (2008) [58], Ellinger et al. (2008) [8], Gordon (2008) [31], Grant (2007) [15], Grant et al. (2010) [6], Greif (2007) [29], Gyllensten \& Palmer (2007) [49], Hauser (2009) [33], Ives (2008) [9], Kemp (2008) [37], Kombarakaran et al. (2008) [5], Kutzhanova et al. (2009) [17], Levleva \& Terry (2008) [56], Mackie (2007) [52], McDowall \& Kurz (2007) [46], Nelson \& Hogan (2009) [32], Newton et al. (2008) [53], Passmore \& Maranetti (2007) [54], Passmore \& Gibbes (2007) [55], Sperry (2008) [21], Stewart et al. (2008) [22], Styhre \& Josephson (2007) [23], Tompson et al. (2008) [1], Ulrich (2008) [25]

Baron \& Morin (2009) [7], Chmielecki (2009) [14], Du Toit (2007) [3], Feggetter (2007) [49], Gordon (2008) [31], Grant (2007) [15], Grant et al. (2010) [6], Greif (2007) [29], Gyllensten \& Palmer (2007) [49], Ives (2008) [9], Kauffman \& Bachkirova (2008) [50], Kombarakaran et al. (2008) [5], Laske (2007) [45], Levleva \& Terry (2008) [56], Linley et al. (2008) [42], Mackie (2007) [52], Matthews (2010) [27], McDowall \& Kurz (2007) [46], Passmore \& Marianetti (2007) [54], Passmore \& Gibbes (2007) [55], Preiss \& Molina-Ray (2007) [20], Stewart et al. (2008) [22], Ulrich (2008) [25]

Beddoes-Jones \& Miller (2007) [30], Baron \& Morin (2009) [7], Chmielecki (2009) [14], Fischer \& Beimers (2009) [4], Gordon (2008) [31], Grant et al. (2010) [6], Greif (2007) [29], Hauser (2009) [33], Ives (2008) [9], Kauffman \& Bachkirova (2008) [50], Kutzhanova et al. (2009) [17], Levleva \& Terry (2008) [56], McDowall \& Kurz (2007) [46], Newton et al. (2008) [53], Stelter (2007) [28], Ulrich (2008) [25] 
Within the literature examined, EC is most often defined, modeled, and rendered effective as a systematic process that results from a collaborative relationship between a coach and a learner where clear mutual goals are contrasted with an assessment of reality. Bridges are then built, most often through discussions that lead the learner to a cycle of self-examination and self-correction. Apart from the definition, models often stress the need for readiness to accept change and studies of effectiveness have identified trust, adaptability, and accountability as avenues to better results. All but adaptability of the process to individual needs may be tied to the commitment of the learner. Establishing a collaborative relationship must be the initial task for without the trust and commitment it includes, building the conditions for change becomes impossible.

While all of this seems familiar to basic problem solving techniques of identifying what we want, what we have, and how best to get there, the unique characteristic of coaching is that the learner, not the coach, must make the decision to improve. Thus, the bridges mentioned above are, ultimately, the responsibility of the learner. The coach is only charged with enhancing the learner's vision of the two former aspects involved in that decision and then allowing change to occur. It is the knowledge of intervention techniques and the ability to choose and fit them appropriately that may enhance a learner's vision of both their aspirations and present state that becomes the catalyst of change.

EC then may be distilled down to two critical tasks: 1) establishing a collaborative relationship, and 2) enhancing the vision of the learner. Effectiveness may determined by development and implementation of a systematic process that may be adapted to each learner. Finally, the coach must have the patience to allow change to occur.

\section{Limitations}

Only peer reviewed journal articles we considered for this study. The authors acknowledge the presence of other credible resources enhancing the study of EC not contained herein. And while the establishment of a 2007-2010 research timeframe supported the objective of discovering new learning on EC, it limits the ability to reach back into the literature to add context, or to connect lines of reasoning outside of the designated time parameter. Finally, definitions of EC, models and approaches used in EC, and measures of effectiveness of the executive coach are certainly important topics of discovery. But much more needs to be learned about EC, from both a scholarly and practical point of view Additional topics can and should be investigated for the purpose of broadening the understanding of EC.

\section{Recommendations for Future Research}

Conspicuous by its absence is empirical research tying characteristics of an effective coach to coaching outcomes. While the broader consideration of the coaching engagement has enjoyed moderate study, more needs to be done to fully understand the contribution of the coach to successful outcomes. Secondly, the lines between consulting, counseling, mentoring and coaching must continue to be defined in order to mitigate confusion over what EC is and what it is not. Finally, EC has been reviled for its paucity of research, favoring an approach to be defined by practice. Abandoning the practical application of research to EC only creates a second wrong that fails to make a right. Researchers and practitioners must make this journey together for the ultimate benefit of all concerned.

\section{References}

[1] Tompson, H.B., Bear, D.J., Dennis, D.J., Vickers, M., London, J. and Morrison, C.L. (2008) Coaching: A Global Study of Successful Practices. American Management Association, New York.

[2] International Coach Federation (2010) http://www.coachfederation.org/

[3] Du Toit, A. (2007) Making Sense through Coaching. Journal of Management Development, 26, 282-291. http://dx.doi.org/10.1108/02621710710732164

[4] Fischer, R.L. and Beimers, D. (2009) "Put Me in, Coach”: A Pilot Evaluation of Executive Coaching in the Nonprofit Sector. Nonprofit Management \& Leadership, 19, 507-522. http://dx.doi.org/10.1002/nml.234

[5] Kombarakaran, F.A., Baker, M.N., Yang, J.A. and Fernandes, P.B. (2008) Executive Coaching: It Works! Consulting Psychology Journal: Practice and Research, 60, 78-90. http://dx.doi.org/10.1037/1065-9293.60.1.78

[6] Grant, A.M., Passmore, J., Cavanagh, M.J. and Parker, H. (2010) The State of Play in Coaching Today: A Comprehensive Review of the Field. International Review of Organizational Psychology, 25, 125-167. 
[7] Baron, L. and Morin, L. (2009) The Coach-Coachee Relationship in Executive Coaching: A Field Study. Human Resource Development Quarterly, 20, 85-106. http://dx.doi.org/10.1002/hrdq.20009

[8] Ellinger, A.D., Hamlin, R.G. and Beattie, R.S. (2008) Behavioral Indicators of Ineffective Managerial Coaching: A Cross National Study. Journal of European Industrial Training, 32, 240-257. http://dx.doi.org/10.1108/03090590810871360

[9] Ives, Y. (2008) What Is “Coaching”? An Exploration of Conflicting Paradigms. International Journal of Evidence Based Coaching and Mentoring, 6, 100-113.

[10] Kampa-Kokesch, S. and Anderson, M.Z. (2001) Executive Coaching: A Comprehensive Review of the Literature. Consulting Psychology Journal: Practice and Research, 53, 205-228. http://dx.doi.org/10.1037/1061-4087.53.4.205

[11] Torraco, R.J. (2005) Writing Integrative Literature Reviews: Guidelines and Examples. Human Resource Development Review, 4, 356-367. http://dx.doi.org/10.1177/1534484305278283

[12] Grant, A.M. (2009) Workplace, Executive and Life Coaching: An Annotated Bibliography from the Behavioral Science and Business Literature (May 2009). Coaching Psychology Unit, University of Sydney, Sydney.

[13] Biswas-Diener, R. (2009) Personal Coaching as a Positive Intervention. Journal of Clinical Psychology, 65, $544-553$. http://dx.doi.org/10.1002/jclp.20589

[14] Chmielecki, M. (2009) Coaching Modern Day Nomads. Journal of Intercultural Management, 1, 135-146.

[15] Grant, A.M. (2007) Enhancing Coaching Skills and Emotional Intelligence through Training. Industrial and Commercial Training, 39, 257-266. http://dx.doi.org/10.1108/00197850710761945

[16] Hui, R.T. and Sue-Chan, C. (2009) Coaching as a Double Edged Sword: The Roles of Goal Orientation and Subjective Task Completion. 8th Industrial and Organizational Psychology Conference, Sydney, 69-74.

[17] Kutzhanova, N., Lyons, T.S. and Lichtenstein, G.A. (2009) Skill-Based Development of Entrepreneurs and the Role of Personal and Peer Group Coaching in Enterprise Development. Economic Development Quarterly, 23, 193-210. http://dx.doi.org/10.1177/0891242409336547

[18] Neenan, M. (2008) From Cognitive Behavior Therapy (CBT) to Cognitive Behavior Coaching (CBC). Journal of Rational Emotional Cognitive Behavior Theory, 26, 1-15. http://dx.doi.org/10.1007/s10942-007-0072-3

[19] Olson, P.O. (2008) A Review of Assumptions in Executive Coaching. The Coaching Psychologist, 4, 151-159.

[20] Preiss, A. and Molina-Ray, C. (2007) Leadership Training for Managers. Journal of Leadership Studies, 1, 10-17. http://dx.doi.org/10.1002/jls.20003

[21] Sperry, L. (2008) Executive Coaching: An Intervention, Role Function, or Profession? Consulting Psychology Journal: Practice and Research, 60, 33-37. http://dx.doi.org/10.1037/1065-9293.60.1.33

[22] Stewart, L.J., O’Riordan, S. and Palmer, S. (2008) Before We Know How We've Done, We Need to Know What We're Doing: Operationalizing Coaching to Provide a Foundation for Coaching Evaluation. The Coaching Psychologist, 4, 127-133.

[23] Styhre, A. and Josephson, P. (2007) Coaching the Site Manager: Effects on Learning and Managerial Practice. Construction Management and Economics, 25, 1295-1304. http://dx.doi.org/10.1080/01446190701466111

[24] Styhre, A., Olilla, S., Wikmalm, L. and Roth, J. (2010) Expert or Speaking Partner? Shifting Roles and Identities in Consulting Work. Leadership \& Organization Development Journal, 31, 159-175. http://dx.doi.org/10.1108/01437731011024402

[25] Ulrich, D. (2008) Coaching for Results. Business Strategy Series, 9, 104-114. http://dx.doi.org/10.1108/17515630810873320

[26] Bowles, S., Cunningham, C.J., De La Rosa, G.M. and Picaon, J. (2007) Coaching Leaders in Middle and Executive Management: Goals, Performance, Buy-In. Leadership \& Organization Development Journal, 28, 388-408. http://dx.doi.org/10.1108/01437730710761715

[27] Matthews, J. (2010) Can Line Managers Ever Be Effective Coaches? Business Leadership Review, 7, 1-10.

[28] Stelter, R. (2007) Coaching: A Process of Personal and Social Meaning Making. International Coaching Psychology Review, 2, 191-201.

[29] Greif, S. (2007) Advances in Research on Coaching Outcomes. International Coaching Psychology Review, 2, 222249.

[30] Beddoes-Jones, F. and Miller, J. (2007) Short-Term Cognitive Coaching Interventions: Worth the Effort or a Waste of Time? The Coaching Psychologist, 3, 60-69.

[31] Gordon, S. (2008) Appreciative Inquiry Coaching. International Coaching Psychology Review, 3, 19-31.

[32] Nelson, E. and Hogan, R. (2009) Coaching on the Dark Side. International Coaching Psychology Review, 4, 9-21.

[33] Hauser, L. (2009) Evidence-Based Coaching: A Case Study. OD Practitioner, 41, 8-13. 
[34] Palmer, S. (2007) Practice: A Model Suitable for Coaching, Counseling, Psychotherapy and Stress Management. The Coaching Psychologist, 3, 71-77.

[35] Passmore, J. (2007) Addressing Deficit Performance through Coaching-Using Motivational Interviewing for Performance Improvement at Work. International Coaching Psychology Review, 2, 265-275.

[36] Passmore, J. (2007) An Integrative Model for Executive Coaching. Coaching Psychology Journal, 59, 68-78.

[37] Kemp, T. (2008) Self-Management and the Coaching Relationship: Exploring Coaching Impact beyond Models and Methods. International Coaching Psychology Review, 3, 32-42.

[38] Barner, R. and Higgins, J. (2007) Understanding Implicit Models That Guide the Coaching Process. Journal of Management Development, 26, 148-158. http://dx.doi.org/10.1108/02621710710726053

[39] Grant, A.M. (2007) A Languishing-Flourishing Model of Goal Striving and Mental Health for Coaching Populations. International Coaching Psychology Review, 2, 250-264.

[40] Spence, G.B. (2007) GAS Powered Coaching: Goal Attainment Scaling and Its Use in Coaching Research and Practice. International Coaching Psychology Review, 2, 155-167.

[41] Govindji, R. and Linley, A. (2007) Strengths Use, Self-Concordance and Well-Being: Implications for Strengths Coaching and Coaching Psychologists. International Coaching Psychology Review, 2, 143-153.

[42] Linley, P.A., Woolston, L. and Biswas-Diener, R. (2009) Strengths Coaching with Leaders. International Coaching Psychology Review, 4, 37-48.

[43] Naficy, K. and Isabella, L. (2008) How Executive Coaching Can Fuel Professional- and Personal-Growth. OD Practitioner, 40, 40-46.

[44] Grant, A.M. and O’Connor, S.A. (2010) The Differential Effects of Solution-Focused and Problem-Focused Coaching Questions: A Pilot Study with Implications for Practice. Industrial and Commercial Training, 42, 102-111. http://dx.doi.org/10.1108/00197851011026090

[45] Laske, O. (2007) Contributions of Evidence-Based Developmental Coaching to Coaching Psychology and Practice. International Coaching Psychology Review, 2, 202-212.

[46] McDowall, A. and Kurz, R. (2007) Making the Most of Psychometric Profiles-Effective Integration into the Coaching Process. International Coaching Psychology Review, 2, 299-309.

[47] Baron, L. and Morin, L. (2010) The Impact of Executive Coaching on Self-Efficacy Related to Management Soft Skills. Leadership \& Organization Development Journal, 31, 18-38. http://dx.doi.org/10.1108/01437731011010362

[48] Feggetter, A.J. (2007) A Preliminary Evaluation of Executive Coaching: Does Executive Coaching Work for Candidates on a High Potential Development Scheme? International Coaching Psychology Review, 2, 129-142.

[49] Gyllensten, K. and Palmer, S. (2007) The Coaching Relationship: An Interpretative Phenomenological Analysis. International Coaching Psychology Review, 2, 168-177.

[50] Kauffman, C. and Bachkirova, T. (2008) Coaching Is the Ultimate Customizable Solution: An Interview with David Peterson. Coaching: An International Journal of Theory, Research and Practice, 1, 114-119.

[51] Kemp, T. (2009) Is Coaching an Evolved Form of Leadership? Building a Trans Disciplinary Framework for Exploring the Coaching Alliance. International Coaching Psychology Review, 4, 105-110.

[52] Mackie, D. (2007) Evaluating the Effectiveness of Executive Coaching: Where Are We Now and Where Do We Need to Be? Australian Psychologist, 42, 310-318. http://dx.doi.org/10.1080/00050060701648217

[53] Newton, N.A., Thompson, J. and Khanna, C. (2008) Workplace Failure: Mastering the Last Taboo. Consulting Psychology Journal: Practice and Research, 60, 227-245. http://dx.doi.org/10.1037/1065-9293.60.3.227

[54] Passmore, J. and Marianetti, O. (2007) The Role of Mindfulness in Coaching. The Coaching Psychologist, 3, $130-136$.

[55] Passmore, J. and Gibbes, C. (2007) The State of Executive Coaching Research: What Does the Current Literature Tell Us and What's Next for Coaching Research? International Coaching Psychology Review, 2, 116-128.

[56] Levleva, L. and Terry, P.C. (2008) Applying Sport Psychology to Business. International Coaching Psychology Review, 3, 8-18.

[57] Cox, E. and Bachkirova, T. (2007) Coaching with Emotion: How Coaches Deal with Difficult Emotional Situations. International Coaching Psychology Review, 2, 178-189.

[58] Day, A., De Haan, E., Sills, C., Bertie, C. and Blass, E. (2008) Coaches’ Experience of Critical Moments in the Coaching. International Coaching Psychology Review, 3, 207-218.

[59] Swanson, R.A. and Holton, E.F. (2009) Foundations of Human Resource Development. 2nd Edition, Berrett-Koehler, San Francisco. 
Scientific Research Publishing (SCIRP) is one of the largest Open Access journal publishers. It is currently publishing more than 200 open access, online, peer-reviewed journals covering a wide range of academic disciplines. SCIRP serves the worldwide academic communities and contributes to the progress and application of science with its publication.

Other selected journals from SCIRP are listed as below. Submit your manuscript to us via either submit@scirp.org or Online Submission Portal.
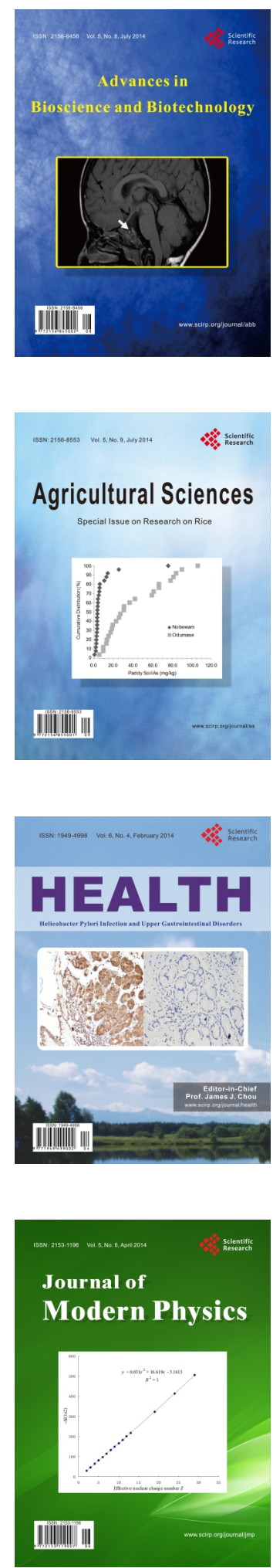
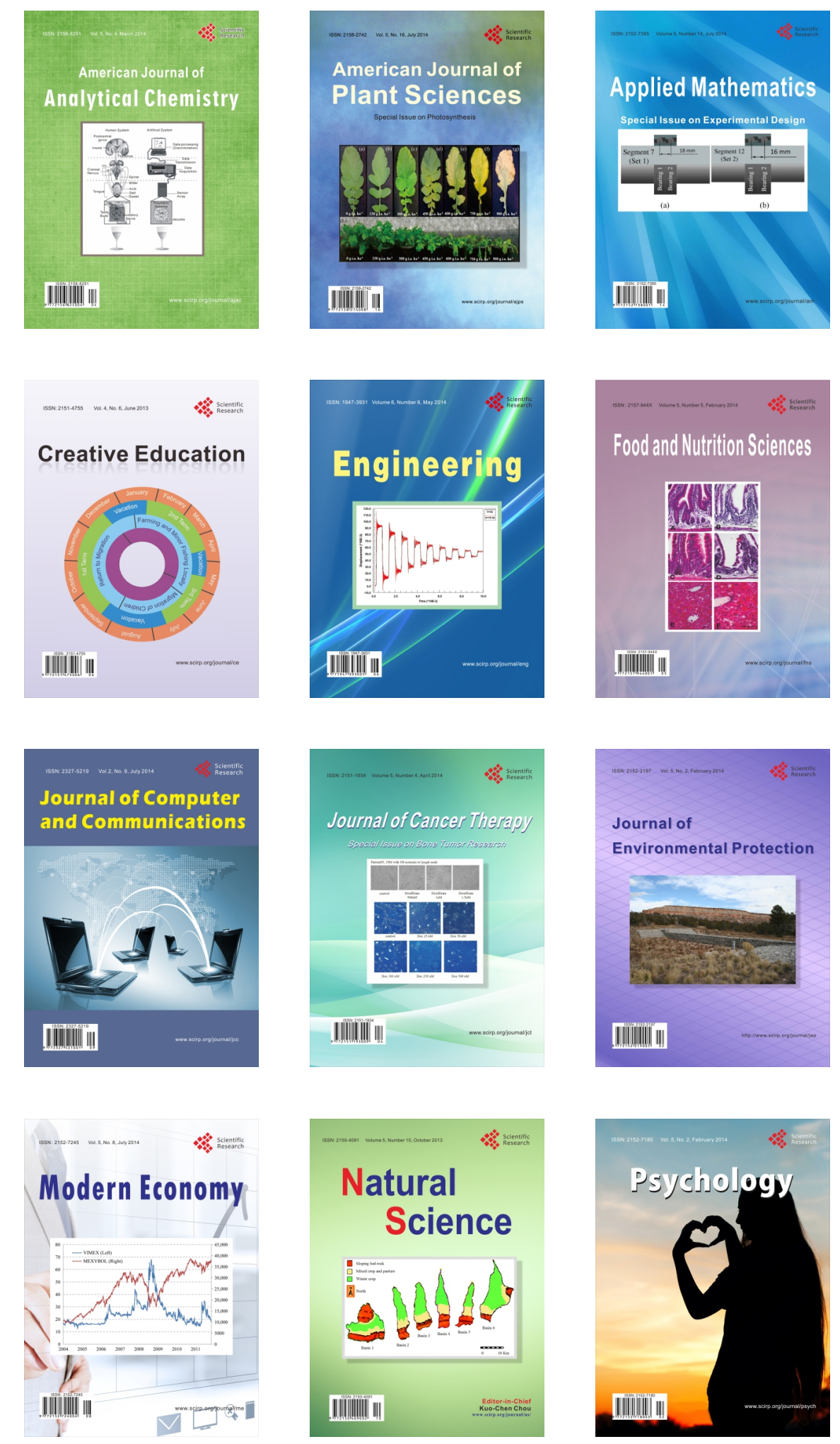